\title{
PENGEMBANGAN LKPD BIOLOGI MATERI EKOSISTEM SEBAGAI MEDIA PEMBELAJARAN KELAS X MA MADANI ALAUDDIN PAO-PAO
}

\section{THE DEVELOPMENT OF BIOLOGY STUDENT WORKSHEET ON ECOSYSTEM MATERIALS AS LEARNING MEDIA FOR CLASS X MA MADANI ALAUDDIN PAO-PAO}

\author{
Ainul Uyuni Taufiq1), Salahuddin'2), Sri Febriani Masdi ${ }^{3)}$ \\ 1,2,3)Fakultas Tarbiyah dan Keguruan Universitas Islam Negeri Alauddin Makassar \\ ainul.uyuni@uin-alauddin.ac.id ${ }^{11}, \underline{\text { salahuddin@uin-alauddin.ac.id }{ }^{2)} \text {, srifebrianimasdi@gmail.com }{ }^{3)}}$
}

\begin{abstract}
Abstrak
Penelitian ini dilakukan dengan tujuan untuk mengembangkan Lembar Kerja Peserta Didik pada materi ekosistem serta untuk mengetahui kevalidan Lembar Kerja Peserta Didik, mengetahui respons peserta didik terhadap Lembar Kerja Peserta Didik, dan mengetahui keefektifan Lembar Kerja Peserta Didik yang dikembangkan. Dalam penelitian ini penulis menggunakan model pengembangan 4-D, yang meliputi empat tahap yaitu pendefinisian (define), perancangan (design), pengembangan (develop), dan penyebaran (disseminate). Subjek penelitian ini adalah peserta didik kelas X MIA 2 MA Madani Alauddin Pao-Pao sebanyak 38 peserta didik. Instrumen penelitian yang digunakan adalah lembar validasi, angket respons peserta didik, dan tes hasil belajar. Teknik pengolahan dan analisis data yang digunakan adalah analisis data kevalidan, analisis data respons peserta didik, dan analisis data keefektifan. Berdasarkan penilaian dari validator ahli, tingkat kevalidan Lembar Peserta Didik yang diperoleh pada penelitian ini yaitu sangat valid dengan nilai rata-rata akhir 3.72, sedangkan berdasarkan angket, respons peserta didik yang diperoleh adalah positif karena diperoleh hasil rata-rata respons peserta didik yaitu 2.95 sehingga produk baik untuk digunakan, sedangkan pada tingkat keefektifan berdasarkan hasil tes peserta didik, diperoleh persentase ketuntasan belajar peserta didik sebanyak 92\%, yang menunjukkan bahwa Lembar Kerja Peserta Didik efektif untuk digunakan.
\end{abstract}

Kata Kunci: 4-D, ekosistem, lembar kerja peserta didik

\begin{abstract}
The purpose of this study was to develop student worksheets on ecosystem material and to determine the validity of student worksheets, find out the responses of students to the student worksheets, and find out the effectiveness of the student worksheets developed. This research and development refers to the 4-D development model, which includes four stages, namely defining, designing, developing, disseminating. The subjects of this study were class X MIA 2 MA Madani Alauddin Pao-Pao students as many as 38 students. The research instruments used were validation sheets, student response questionnaires, and learning outcomes tests. Data processing and analysis techniques used are validity data analysis, analysis of student response data, and effectiveness data analysis. Based on the assessment of the expert validator, the level of validity of the student worksheets obtained in this study is very valid with a final average value of 3.72. While based on the questionnaire, the responses of students obtained are positive because the results of the average response of students are 2.95 so that the product is good to use. While at the level of effectiveness based on the test results of students, the percentage of students' learning completeness was 92\%, which showed that the student worksheets was effective to use.
\end{abstract}

Keywords: 4-D, ecosystem, student worksheet 
How to Cite: Taufiq, A.U., Salahuddin, \& Masdi, S.F. (2019). Pengembangan LKPD biologi materi ekosistem sebagai media pembelajaran kelas X MA Madani Alauddin Pao-Pao. AlAsma: Journal of Islamic Education, 1(2), 63-75.

\section{PENDAHULUAN}

Jika dilihat dari arti yang paling sederhana, pendidikan dapat diartikan sebagai kegiatan yang dilakukan oleh manusia dengan tujuan untuk lebih memperbaiki kepribadian peserta didik sesuai dengan nilai-nilai yang ada di dalam masyarakat dan kebudayaannya. Dalam perkembangannya, istilah pendidikan atau pedagogik merupakan proses pengajaran yang diberikan oleh seseorang dengan kesadaran yang penuh guna mengubah seseorang menjadi lebih dewasa. Selanjutnya, pendidikan diartikan sebagai suatu usaha yang dilakukan oleh beberapa orang atau sekelompok orang dengan tujuan untuk mendewasakan orang lain agar dapat lebih meningkatkan kehidupannya baik dari segi material maupun mental. Namun, arti pendidikan ini tentunya akan selalu mengalami perkembangan mengikuti zaman, meskipun secara esensial tidak jauh berbeda. (Hasbullah, 2009:01).

Pendidikan nasional memiliki fungsi untuk menciptakan karakter serta meningkatkan kemampuan seseorang menjadi lebih baik guna meningkatkan peradaban Negara dengan bangsa yang mejadi lebih cerdas. Hal ini dilakukan dengan tujuan untuk mengembangkan keterampilan yang dimiliki oleh peserta didik agar menjadi manusia yang beriman dan bertakwa kepada Tuhan Yang Maha Esa, berakhlak mulia, sehat, berilmu, cakap, kreatif, mandiri, dan menjadi warga Negara yang demokratis serta tanggungjawab. (UU RI No. 20 Tahun 2003).

Pengetahuan dan pemahaman peserta didik didukung oleh perangkat belajar dalam melakukan kegiatan pembelajaran guna menciptakan proses pembelajaran yang lebih berkesan untuk para siswa. Oleh karenanya media maupun perangkat yang mendukung dalam pembelajaran harus diperbahrui yaitu dengan jalan dikembangkannya media maupun perangkat pembelajaran tersebut agar memudahkan peserta didik di sekolah internasional, salah satu solusinya adalah Lembar Kerja Peserta Didik (LKPD). Menggunakan Lembar Kerja Peseta Didik (LKPD) dalam proses belajar dapat meningkatkan kemampuan peserta didik memahami materi. (Merdekawati \& Lestari, 2011)

Lembar Kerja Peserta Didik (LKPD) atau yang biasa disebut Lembar Kerja Siswa (LKS) ialah perangkat pendukung pembelajaran yang apabila digunakan pada pembelajaran akan sangat mendukung proses pembelajaran tersebut baik secara individu peserta didik maupun secara berkelompok, karena dengan LKPD akan memberikan banyak wawasan yang baru kepada peserta didik. (Alvina Putri Purnama Sari dan Agil Lepiyanto, 2016: 42).

LKPD bertujuan untuk mendukung serta meningkatkan antusias peserta didik dalam pembelajaran agar bisa lebih meningkatkan pengetahuannya terhadap materi, keterampilan dan sikapnya. Adanya lembar kerja bisa menciptakan pembelajaran yang lebih baik dan aktif. LKPD memiliki fungsi lain, yaitu: (1) dapat digunakan oleh guru sebagai alat untuk menciptakan pembelajaran yang sistematis; (2) membantu meningkatkan keaktifan peserta didik; (3) dapat meningkatkan keingintahuan peserta didik terhadap apa yang diajarkan jika LKPD dikemas dengan baik; (4) menimbulkan rasa 
percaya terhadap diri sendiri dan meningkatkan motivasi belajar peserta didik; serta (5) mengembangkan skill peserta didik pada penyelesaian suatu masalah. (Sumarmi dkk, 2016: 316).

Pengintegrasian pelajaran umum (khusus pelajaran biologi) dengan pelajaran agama (Islam) di lingkungan institusi pendidikan umum maupun di institusi pendidikan agama mulai pendidikan dasar hingga perguruan tinggi di Indonesia merupakan keniscayaan (mutlak). Keniscayaan ini didasarkan atas dasar filosofi "Pancasila". Indikasi filosofi Pancasila sebagai landasan pengintegrasian keilmuan ada pada sila yang pertama, yaitu "pengakuan kepada Tuhan Yang Maha Esa". Sila yang kesatu ini menunjukkan bahwa semua ilmu bersumber dari Tuhan Yang Maha Esa. Adapun karsa manusia hanya merekayasa ciptaan Tuhan Yang Maha Esa sehingga ciptaan Tuhan Yang Maha Esa menjadi suatu ilmu. (Anda Junanda, 2015: 1).

Pendidikan ilmu sains yaitu ilmu biologi yang diajarkan di sekolah-sekolah tentunya akan lebih bermakna apabila dalam proses pembelajarannya diadakan pengintegrasian dengan ilmu akidah dan akhlak. Hal ini dilakukan agar tujuan pendidikan nasional Indonesia dapat terpenuhi, karena sebagaimana yang kita ketahui, tujuan pendidikan nasional sangat menitikberatkan pada akhlak mulia bangsa Indonesia. Oleh karena itu, haruslah diadakan suatu model pembelajaran yang di dalamnya terdapat pengintegrasian antara matei dengan ilmu akidah dan akhlak. (Nashruddin Yusuf, 2010: 224).

Berdasarkan observasi awal yang dilakukan pada hari rabu tanggal 06 Desember 2017 di MA Madani Alauddin Pao-Pao dengan mewawancarai guru mata pelajaran biologi pada kelas 10, ditemukan fakta bahwa Lembar Kerja Peserta Didik yang digunakan oleh guru di kelas X MIA 2 khususnya pada materi ekosistem masih sangat sederhana. Format penulisan dari LKPD yang digunakan masih belum mengikuti format penulisan LKPD yang seharusnya dan juga pada LKPD yang digunakan oleh guru belum terdapat integrasi Islam atau unsur Islam di dalamnya. Lembar Kerja Peserta Didik yang digunakan hanya terfokus pada materinya saja, sedangkan sekolah MA Madani Pao-Pao sendiri merupakan sekolah yang tergolong ke dalam sekolah dengan basis Islam karena menyandang nama madrasah.

Merujuk pada penjelasan di atas, maka penulis memutuskan untuk mengambil judul penelitian tentang "Pengembangan LKPD Biologi Pada Materi Ekosistem Sebagai Media Pembelajaran Pada Kelas X MA Madani Alauddin Pao-Pao", yang fokus pengembangan produk LKPD yaitu pada aspek integrasi antara materi dengan Islam serta aspek format penulisan LKPD.

\section{METODE PENELITIAN}

Jenis penelitian yang digunakan adalah penelitian pengembangan (research and development). Research and development adalah jenis penelitian yang di dalamnya akan menghasilkan suatu produk yang teruji keefektifannya. (Sugiyono, 2013: 407). Uji coba hasil pengembangan produk LKPD yang dihasilkan akan dilaksanakan di MA Madani PaoPao dengan kelas X MIA 2 sebagai subjek uji coba dengan jumlah peserta didik sebanyak 38 orang.

Pengembangan dilakukan dengan mengacu pada model pengembangan 4D, di mana terdiri dari 4 tahapan pengembangan yaitu: (1) Define (pembatasan), (2) Design (perancangan), (3) Develop (pengembangan), dan (4) Dessiminate (penyebaran). Selain itu, 
digunakan lembar validasi, angket respon peserta didik, dan tes hasil belajar sebagai instrumen penelitian. Lembar validasi nantinya akan digunakan untuk menentukan tingkat kevalidan dari produk yang dibuat. Angket respon peserta didik digunakan untuk mengetahui apakah produk yang dibuat baik untuk digunakan. Tes hasil belajar digunakan dalam penelitian agar dapat menentukan tingkat keefektifan produk.

Teknik pengumpulan data terdiri atas tiga yaitu data uji kevalidan yang diperoleh dari lembar validasi, data uji respon peserta didik yang diperoleh dari instrumen penelitian berupa angket respon peserta didik, serta data uji keefektifan yang diperoleh dari instrumen penelitian berupa tes hasil.

Data yang telah diperoleh kemudian dianalisis. Analisis data dilakukan untuk menentukan tingkat kevalidan, keefektifan, dan respon peserta didik terhadap produk yang dikembangkan yaitu lembar kerja peserta didik.

Adapun analisis data kevalidan menurut Nahdaturrugaisiyah (2014:35) dilakukan sebagai berikut:

a. Menentukan rekapitulasi hasil penilaian ahli ke dalam tabel yang meliputi: aspek $\left(\bar{A}_{l}\right)$ dan nilai total $\left(\overline{V_{l j}}\right)$ untuk masing-masing validator.

b. Menentukan rata-rata nilai hasil validasi dari semua validator untuk setiap kriteria dengan rumus:

$$
\overline{K i}=\frac{\sum_{j=1}^{n} \overline{V_{l}}}{n}
$$

Keterangan:

$\overline{K i}=$ rata-rata kriteria ke-i

$\overline{V i j}=$ nilai hasil penilaian terhadap kriteria ke-i oleh validator ke-j

$\mathrm{n}$ = jumlah validator

c. Menentukan rata-rata nilai untuk setiap aspek dengan rumus:

$$
\overline{A i}=\frac{\sum_{j=1}^{n} \overline{K i j}}{n}
$$

Keterangan:

$\overline{A i}=$ rata-rata nilai untuk aspek ke-i

$\bar{K} \boldsymbol{i j}$ = rata-rata untuk aspek ke-i kriteria ke-j

$\mathrm{n}$ = banyaknya kriteria

d. Mencari rata-rata total $(\overline{V a})$ dengan rumus:

$$
\overline{V a}=\frac{\sum_{i=1}^{n} \overline{A i}}{n}
$$

Keterangan:

$\overline{V a}_{=}$rata-rata total

$\overline{A i}=$ rata-rata aspek ke-i

$\mathrm{n}$ = banyaknya aspek 
e. Menentukan kategori validitas setiap kriteria $(\overline{K i})$ atau $\operatorname{rata-rata} \operatorname{aspek}(\overline{A i})$ atau rata-rata total ( $\overline{V a}$ ) dengan kategori validasi yang telah ditetapkan.

Adapun kategori validitas menurut Subana adalah sebagai:

Tabel 1. Kriteria Kevalidan

\begin{tabular}{cc}
\hline Nilai & Kriteria \\
\hline $3.5 \leq V a \leq 4$ & Sangat Valid \\
$2.5 \leq V a<3.5$ & Valid \\
$1.5 \leq V a<2.5$ & Cukup Valid \\
$0 \leq V a<1.5$ & Tidak Valid \\
\hline
\end{tabular}

Keterangan :

$V a=$ nilai rata-rata kevalidan dari semua validator. (Nahdaturrugaisiyah, 2014:35)

Sedangkan menurut Ridwan (2003: 102), analisis data hasil respon peserta didik dilakukan dengan cara, yaitu:

a. Melakukan rekapitulasi hasil penelitian ahli ke dalam tabel yang meliputi: aspek (Ai) dan nilai total (Vij) untuk masing-masing validator.

b. Mencari rerata total (Xi) dengan rumus :

$$
X i=\frac{\sum_{i=0}^{n} A i}{n}
$$

Keterangan:

$\mathrm{Ai}=$ rerata aspek

$\mathrm{n}$ = banyaknya aspek

c. Menentukan kategori validasi setiap kriteria (Ki) atau rerata aspek (Ai) atau rerata total (Xi) dengan kategori validasi yang telah ditetapkan.

Tabel 2. Kategori Tingkat Kepraktisan

\begin{tabular}{cc}
\hline Nilai & Kriteria \\
\hline $3.5 \leq X i \leq 4$ & Sangat Positif \\
$2.5 \leq X i<3.5$ & Positif \\
$1.5 \leq X i<2.5$ & Cukup Positif \\
$0 \leq X i<1.5$ & Tidak Positif \\
\hline
\end{tabular}

Keterangan :

Xi = Nilai Rata-Rata Responden. (Ridwan, 2003: 35)

Sedangkan keefektifan Lembar Kerja Peserta Didik (LKPD) yang dibuat dan dikembangkan ditentukan dengan menganalisis data pengukuran hasil belajar peserta didik. Peserta didik dikatakan berhasil (tuntas) apabila memperoleh nilai lebih besar atau sama dengan nilai KKM (nilai $\geq$ KKM). Pembelajaran dikatakan berhasil secara klasikal jika minimal 80\% peserta didik mencapai nilai tuntas. (Widoyoko, 2014: 242). 
Tabel 3. Interval Skor Penentuan Hasil Belajar Peserta Didik

\begin{tabular}{ccc}
\hline No. & Persentase Ketuntasan & Kriteria \\
\hline 1. & $p>80$ & Sangat efektif \\
2. & $60<p \leq 80$ & Efektif \\
3. & $40<p \leq 60$ & Cukup efektif \\
4. & $20<p \leq 40$ & Kurang efektif \\
5. & $p \leq 20$ & Sangat kurang \\
& & efektif \\
\hline
\end{tabular}

Keterangan $p=$ persentase peserta didik yang tuntas (Widoyoko, 2014: 242).

\section{HASIL DAN PEMBAHASAN}

Berikut uraian hasil yang diperoleh dari semua tahapan dalam proses pengembangan produk Lembar Kerja Peserta Didik (LKPD) pada materi ekosistem beserta hasil uji coba produk tersebut.

Tahap Pendefinisian (Define) terdiri dari empat tahapan yaitu: (1) Tahap analisis awal-akhir dimana peneliti melakukan pengidentifikasian terhadap permasalahan yang dialami selama proses pembelajaran pada kelas yang akan dilakukan penelitian. Dari hasil observasi yang dilakukan di MA Madani Alauddin Pao-Pao ditemukan beberapa masalah yaitu pada proses pembelajaran yang dilakukan dikelas X MIA 2 MA Madani Pao-Pao masih terfokus pada guru mata pelajaran saja, peserta didik jarang sekali terlibat aktif dalam proses pembelajaran. Selain itu, LKPD yang digunakan masih sangat sederhana tanpa mengikuti struktur penulisan LKPD serta belum ada integrasi antara materi dalam LKPD dengan Islam, (2) Analisis peserta didik adalah tahapan agar peneliti memperoleh karakteristik dari peserta didik yang nantinya akan dijadikan sebagai subjek uji coba produk. Berdasarkan observasi yang telah dilakukan di kelas X MIA 2 diperoleh hasil yaitu kemampuan akademik peserta didik pada kelas X MIA 2 memiliki tingkat keragaman berbeda, dimana kemampuan peserta didik terdiri dari beberapa kategori yaitu tinggi, sedang, dan rendah berdasarkan hasil belajar peserta didik. Selain itu, materi ekosistem telah diperoleh oleh peserta didik di sekolah menengah pertama (SMP) sehingga peserta didik di kelas X MIA 2 telah memiliki pengalaman belajar pada materi tersebut, sedangkan tingkat keaktifan peserta didik pada saat belajar masih sangat kurang sebagai akibat dari lebih aktifnya guru dari pada peserta didik sehingga mengurangi kemampuan peserta didik tersebut dalam memecahkan masalah. (3) Analisis materi yaitu untuk menentukan materi yang tepat untuk digunakan dalam pengembangan produk. Analisis materi pada penelitian dilakukan dengan cara mengidentifikasi materi apa yang sesuai dengan produk yang akan dikembangkan. Adapun materi yang digunakan oleh peneliti dalam pengembangan produk yaitu materi ekosistem dimana dalam kurikulum 2013 terkhusus pada materi ekosistem, peserta didik lebih dianjurkan untuk melakukan pengamatan terhadap lingkungan sekitarnya berdasarkan materi ekosistem. Maka dari itu, peneliti memilih materi tersebut karena sesuai dengan produk yang akan dikembangkan yaitu Lembar Kerja Peserta Didik yang didalamnya berisi tugas-tugas (masalah) yang dapat dipecahkan berdasarkan hasil pembelajaran yang diperoleh di dalam kelas maupun pengamatan di luar kelas. (4) Merumuskan tujuan adalah tahap untuk membuat dan 
menentukan tujuan pembelajran yang merujuk pada analisis materi. Perumusan tujuan pembelajaran mengacu pada kompetensi dasar dan indikator. Hasil dari perumusan tujuan yang telah dibuat akan dijadikan sebagai acuan dalam mengembangkan produk. Adapun rincian tujuan pembelajaran pada materi ekosistem sebagai berikut :

Tabel 4. Tujuan Pembelajaran

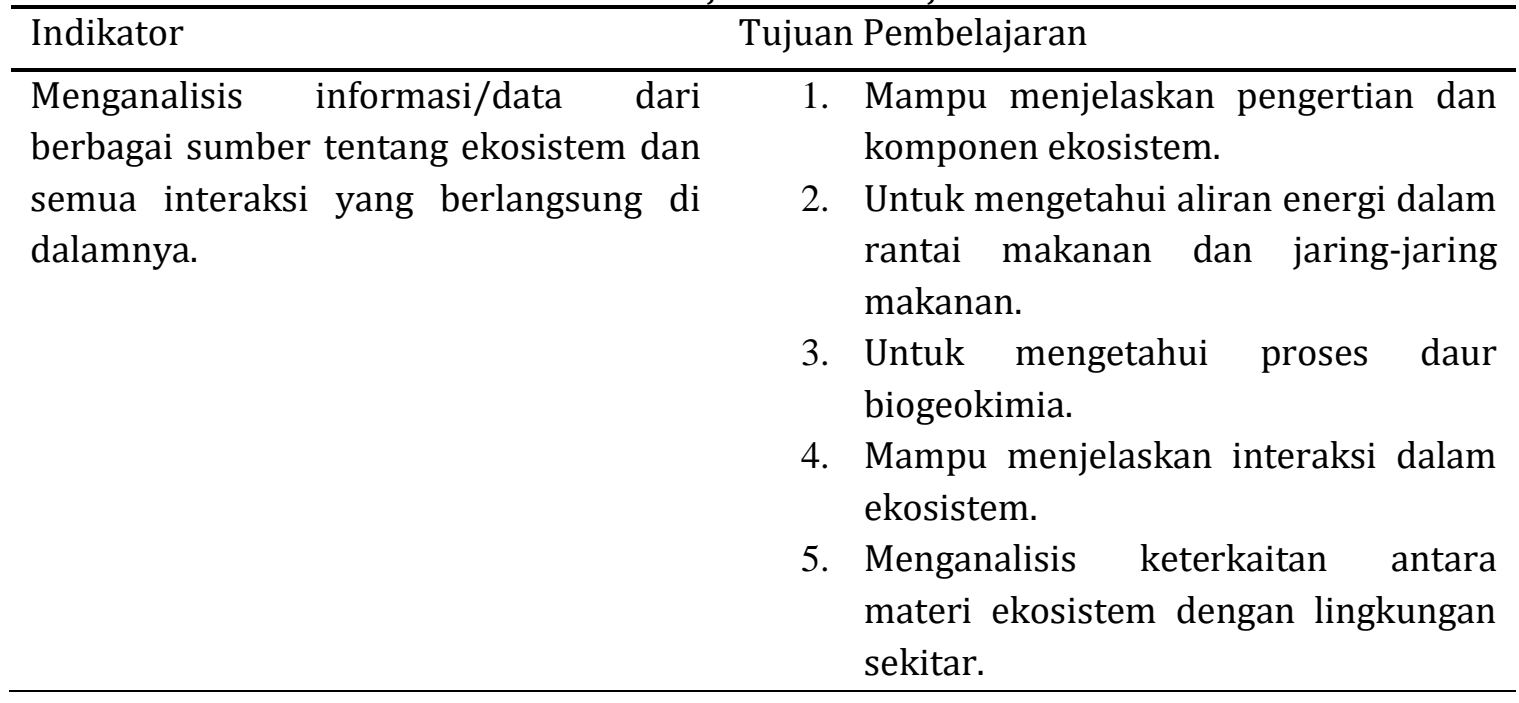

Tahap Perancangan (Design) memiliki beberapa tahap yaitu: (1) Penyusunan tes, pada tahap ini dilakukan penyusunan instrumen tentang tes kemampuan peserta didik dalam bentuk tes hasil belajar dalam bentuk pilihan ganda yang berpatokan pada kisi-kisi soal yang sebelumnya telah dibuat oleh peneliti yang akan digunakan setelah seluruh materi telah diajarkan, (2) Pemilihan perangkat pembelajaran yang sesuai, dimana pada tahap ini media yang dipilih adalah Lembar Kerja Peserta Didik karena menurut peneliti materi yang diambil yaitu materi ekosistem sangat sesuai dengan penggunaan LKPD pada saat proses pembelajaran sedang berlangsung, (3) Pemilihan format, dilakukan dengan tujuan untuk menentukan bagaimana format yang akan digunakan sebagai acuan dalam penyusunan produk LKPD yang akan dibuat. Adapun format penyusunan produk LKPD yang dipilih oleh peneliti adalah format yang dikemukakan oleh Andi Prastowo yang terdiri dari judul, kompetensi dasar yang akan dicapai, waktu penyelesaian, peralatan/bahan yang diperlukan untuk menyelesaikan tugas, informasi singkat, langkah kerja dan tugas yang harus dilakukan, dan laporan/tugas yang harus dikerjakan, (4) Rancangan awal, adapun rancangan awal peneliti terhadap produk LKPD yaitu LKPD akan disusun berdasarkan format penyusunan yang telah ditentukan sebelumnya, dan juga beracuan pada kurikulum 2013. Adapun Lembar Kerja Peserta Didik yang dirancang sebanyak 2 kegiatan yang akan digunakan pada 3 pertemuan yang tugas-tugasnya akan dikerjakan secara berkelompok. Adapun tugas-tugas yang dimuat dalam produk LKPD terdiri dari dua macam yaitu tugas yang nantinya akan dikerjakan di dalam kelas, dan tugas yang akan dikerjakan diluar kelas setelah melakukan pengamatan lingkungan sekolah. Selain memperhatikan format penyusunan LKPD, peneliti juga menekankan pada integrasi antara materi dengan Islam, yaitu akan dilakukan pengintegrasian materi ekosistem dengan Islam pada bagian informasi materi pada LKPD, dan juga akan 
dihadirkan beberapa pertanyaan pada LKPD tentang ekosistem yang berkaitan dengan keislaman.

Tahap Pengembangan (Develop), pada tahap ini dilakukan pengembangan terhadap LKPD dimana pengembangannya berpatokan pada rancangan awal pada tahap sebelumnya sehingga menghasilkan produk awal yang disebut prototype I yang kemudian selanjutnya akan divalidasi oleh validator. Terdapat dua validator ahli yang akan menilai tingkat kevalidan produk dan instrument. Selanjutnya hasil yang diperoleh dari validator ahli kemudian dijadikan sebagai saran dan masukan untuk kemudian dijadikan sebagai acuan dalam merevisi produk LKPD hingga menghasilkan prototype II. Terdapat beberapa saran perbaikan dari validator ahli terhadap produk LKPD prototype I, adalah :

Tabel 5. Saran Revisi oleh Validator

\begin{tabular}{|c|c|}
\hline Validator & Saran \\
\hline Validator desain & $\begin{array}{l}\text { 1. Memperbaiki kesalahan penulisan ayat } \\
\text { 2. Membuat aktivitas yang mendorong siswa memecahkan } \\
\text { sendiri aliran energi dalam rantai makanan (dalam } \\
\text { bentuk soal). } \\
\text { 3. Membuat aktivitas yang dapat menghubungkan materi } \\
\text { dengan lingkungan sekolah. } \\
\text { 4. Memperhatikan kesalahan huruf pada LKPD }\end{array}$ \\
\hline Validator materi & $\begin{array}{l}\text { 1. Menyesuaikan informasi materi dengan tujuan } \\
\text { pembelajaran. } \\
\text { 2. Menggunakan teori yang relevan } \\
\text { 3. Jumlah soal sesuai dengan tujuan pembelajaran }\end{array}$ \\
\hline
\end{tabular}

Setelah dinyatakan valid oleh validator, lembar validasi produk kemudian diisi oleh validator dan dianalisis untuk menentukan tingkat kevalidan dari produk.

Berikut adalah rangkuman hasil validasi produk dari kedua validator terhadap aspek-aspek yang telah ditentukan:

Tabel 6. Hasil Validasi Produk LKPD

\begin{tabular}{|c|c|c|c|}
\hline No. & Aspek yang dinilai & Hasil Penilaian & Kategori \\
\hline 1. & Format & 3.5 & Sangat valid \\
\hline 2. & Bahasa & 3.6 & Sangat valid \\
\hline 3. & Isi & 3.5 & Sangat valid \\
\hline 4. & Waktu & 4 & Sangat valid \\
\hline 5. & Manfaat/kegunaan & 4 & Sangat valid \\
\hline & Rata-rata penilaian total & 3.72 & Sangat valid \\
\hline
\end{tabular}

Dari tabel 6 dapat dilihat bahwa nilai dari semua aspek pengamatan yang dinilai yaitu format, bahasa, isi, waktu, dan manfaat/kegunaan yang diberikan oleh validator pada lembar validasi berada dalam kategori sangat valid, sehingga dari nilai yang 
diberikan oleh kedua validator tersebut maka diperoleh rata-rata kevalidan prototype II secara keseluruhan adalah 3.72, maka produk LKPD prototype II berada pada kategori sangat valid karena berada pada interval $p>80$. Hasil tersebut sesuai dengan teori dalam jurnal yang ditulis oleh Riti Desmiwati, Ratnawulan, dan Yulkifli pada penelitiannya yang menyatakan bahwa produk dikatakan valid apabila mencakup beberapa komponen yaitu: (1) komponen kelayakan isi mencakup kesesuaian SK dengan KD, kebutuhan, kebenaran substansi, manfaat, nilai moral, dan nilai sosial. (2) Komponen penyajian (construct), mencakup kejelasan tujuan yang ingin dicapai, urutan penyajian, pemberian motivasi, daya tarik, interaksi (pemberian stimulus dan respon) dan kelengkapan informasi. (3) Komponen kebahasaan, mencakup keterbatasan, kejelasan informasi, kesesuaian dengan kaidah bahasa Indonesia, penggunaan bahasa secara efektif dan efisien, yang kemudian semua komponen tersebut akan dinilai oleh validator pada lembar validasi untuk menentukan tingkat kevalidan produk berdasarkan kriteria kevalidan (Riti Desmiwati, Ratnawulan, dan Yulkifli, 2017: 33).

Analisis respons peserta didik bertujuan untuk mengetahui bagaimana respon peserta didik terhadap produk yang telah dibuat dan dikembangkan sebelumnya. Berikut rangkuman data respon peserta didik terhadap Lembar Kerja Peserta Didik (LKPD) berdasarkan hasil angket respon peserta didik:

Tabel 7. Hasil Persentase Analisis Data Angket Respon Peserta Didik

\begin{tabular}{|c|c|c|c|c|c|c|}
\hline \multirow{2}{*}{ No. } & \multirow{2}{*}{ Pernyataan } & \multicolumn{4}{|c|}{ Skor Soal } & \multirow[t]{2}{*}{$\sum$} \\
\hline & & 1 & 2 & 3 & 4 & \\
\hline 1. & $\begin{array}{l}\text { Saya merasa antusias mengikuti pembelajaran } \\
\text { biologi terkhusus materi ekosistem dengan } \\
\text { bantuan LKPD. }\end{array}$ & & 1 & 31 & 6 & 3.13 \\
\hline 2. & $\begin{array}{l}\text { Isi dari LKPD materi ekosistem yang digunakan } \\
\text { pada proses pembelajaran cukup jelas sehingga } \\
\text { mudah dimengerti. }\end{array}$ & & 3 & 23 & 12 & 3.24 \\
\hline 3. & $\begin{array}{l}\text { Isi dari LKPD materi ekosistem tersusun rapih } \\
\text { dan sistematis sehingga mudah dipahami }\end{array}$ & & 3 & 23 & 12 & 3.24 \\
\hline 4. & $\begin{array}{l}\text { Kegiatan yang dilakukan pada LKPD telah } \\
\text { sesuai dengan materi pokok ekosistem. }\end{array}$ & & & 27 & 11 & 3.29 \\
\hline 5. & $\begin{array}{l}\text { Petunjuk kegiatan pada LKPD materi ekosistem } \\
\text { cukup jelas sehingga memudahkan saya untuk } \\
\text { melakukan kegiatan pembelajaran. }\end{array}$ & 1 & 2 & 23 & 10 & 3 \\
\hline 6. & $\begin{array}{l}\text { Kegiatan yang dilakukan pada LKPD materi } \\
\text { ekosistem membantu saya dalam bekerja sama } \\
\text { dengan teman kelompok saya. }\end{array}$ & & 2 & 28 & 8 & 3.16 \\
\hline 7. & $\begin{array}{l}\text { Bahasa yang digunakan pada LKPD cukup jelas } \\
\text { sehingga mudah dipahami. }\end{array}$ & 2 & 5 & 20 & 11 & 3.05 \\
\hline 8. & $\begin{array}{l}\text { Gaya penyajian Lembar Kerja Peserta didik } \\
\text { (LKPD) yang digunakan pada materi ekosistem } \\
\text { ini membosankan. }\end{array}$ & 9 & 13 & 10 & 6 & 2.34 \\
\hline 9. & $\begin{array}{l}\text { Tugas-tugas yang disajikan dalam LKPD sangat } \\
\text { membantu dalam memahami materi ekosistem. }\end{array}$ & 3 & 1 & 24 & 10 & 2.45 \\
\hline
\end{tabular}




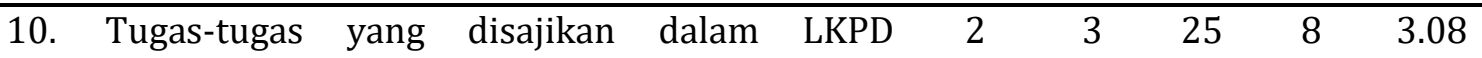
membantu saya dalam mengaitkan antara materi ekosistem dengan lingkungan sekitar.

11. Tugas-tugas yang disajikan dalam LKPD materi ekosistem memicu saya untuk lebih aktif dalam pembelajaran biologi materi ekosistem.

12. LKPD yang digunakan pada materi ekosistem sangat membosankan.

13. LKPD matei ekosistem yang digunakan telah sesuai dengan kebutuhan saya.

14. LKPD yang digunakan pada materi ekosistem membantu terlaksananya proses pembelajaran biologi.

\begin{tabular}{cl}
\hline Total & 41.24 \\
\hline Rata-Rata Akhir & 2.95 \\
\hline Kriteria Penilaian & Positif \\
\hline
\end{tabular}

Dari tabel 7 dapat dilihat bahwa diperoleh total persentase respon peserta didik sebesar 41.24 dengan rata-rata akhir yaitu 2.95, sehingga diperoleh kriteria penilaian yaitu positif karena hasil rata-rata akhir berada pada interval $2,5 \leq X i<3,5$. Hal tersebut menunjukkan bahwa Lembar Kerja Peserta Didik (LKPD) yang dibuat dan dikembangkan mendapat respon positif dari peserta didik. Hal ini sesuai dengan teori dalam jurnal penelitian oleh Lutfikha Hikmatun Nissa dan Sukardiyono pada penelitiannya yang menyatakan bahwa respon peserta didik terhadap LKPD diukur melalui analisis data hasil angket respon peserta didik. Analisis respon peserta didik dilakukan untuk menentukan kualitas produk yang dikembangkan berdasarkan hasil respon peserta didik setelah menggunakan produk dalam proses pembelajaran. (Lutfikha Hikmatun Nissa dan Sukardiyono, 2017: 70).

Analisis keefektifan dilakukan untuk mengetahui tingkat keefektifan produk yang telah dibuat dan dikembangkan sebelumnya. Berdasarkan dari analisis hasil Tes Hasil Belajar peserta didik maka dapat menentukan tingkat keefektifan produk. Berikut tabel persentase ketuntasan belajar peserta didik kelas X MIA 2 MA Madani Alauddin Pao-Pao:

Tabel 8. Presentase Ketuntasan Belajar Peserta Didik

\begin{tabular}{clcc}
\hline No. & Ketuntasan peserta didik & Jumlah & KKM \\
\hline 1. & Peserta didik yang tuntas & 35 & 75 \\
2. & Peserta didik yang tidak tuntas & 3 & \\
& Persentase ketuntasan belajar & $92 \%$ & \\
\hline
\end{tabular}

Tabel 8 menunjukkan bahwa ketuntasan nilai belajar peserta didik pada materi ekosistem yaitu sebanyak 35 orang peserta didik mendapatkan nilai berada di atas KKM sehingga 35 orang tersebut dinyatakan tuntas, sedangkan 3 orang peserta didik memperoleh nilai dibawah KKM sehingga dinyatakan tidak tuntas. Dari hasil tersebut, maka diperoleh persentase ketuntasan belajar siswa sebesar 92\%. Adapun kriteria pada syarat ketuntasan belajar yaitu nilai individu peserta didik harus mencapai nilai minimal 
75 dan secara klasikal minimal $80 \%$ peserta didik mencapai ketuntasan minimum (KKM). Maka dari hasil tersebut produk Lembar Kerja Peserta Didik (LKPD) pada materi ekosistem dinyatakan sangat efektif. Hasil tersebut didukung oleh teori yang dikemukakan oleh S. Eko Putro Widoyoko yang menyatakan bahwa peserta didik dikatakan berhasil (tuntas) apabila memperoleh nilai lebih besar atau sama dengan nilai KKM (nilai $\geq K K M$ ). Pembelajaran dikatakan berhasil secara klasikal jika minimal $80 \%$ peserta didik mencapai nilai tuntas (Widoyoko, 2014: 242).

Tahap penyebaran (Dessiminate), merupakan tahap yang dilakukan dengan tujuan untuk memperkenalkan produk serta untuk lebiih menguji keefektifan produk dalam skala yang besar. Adapun penyebaran dilakukan oleh peneliti di sekolah MA Pondok Pesantren Ash-Shalihin Gowa yang beralamat di Jl. Mustafa Daeng Bunga No.183, Paccinongang, Somba Opu, Kabupaten Gowa, Sulawesi Selatan. Penyebaran dilakukan dalam skala terbatas yang dilaksanakan dengan cara melakukan sosialisasi tentang produk Lembar Kerja Peserta Didik (LKPD) di kelas X MIA serta pemberian satu buah produk LKPD yang telah dikemas sebagai perwakilan produk dan juga pemberian file LKPD kepada tenaga pengajar bidang studi biologi disekolah tersebut.

Lembar Kerja Peserta Didik (LKPD) pada materi ekosistem yang dibuat dikembangkan menggunakan 4 tahapan dari model pengembangan 4D masih memiliki beberapa keterbatasan yaitu: (1) Lembar Kerja Peserta Didik (LKPD) pada materi ekosistem yang dihasilkan hanya dibuat pada materi ekosistem sehingga hanya dapat digunakan pada satu materi saja, (2) Dalam penelitian menggunakan LKPD yang dikembangkan hanya dilakukan pada satu kelas saja sehingga belum mampu melibatkan peserta didik dalam jumlah yang besar, (3) Dalam LKPD yang dibuat masih banyak kekurangan terutama pada bagian pengintegrasian antara materi dengan Islam. Adapun pada bagian tersebut pengintegrasian materi dengan Islam hanya dengan menggunakan ayat al-Qur'an saja, belum terdapat contoh hadist maupun nilai-nilai Islam yang lebih bisa menguatkan aspek integrasi.

Selain itu, terdapat beberapa kelebihan pada penelitian ini yaitu: (1) Dengan dibuatnya Lembar Kerja Peserta Didik (LKPD) pada materi ekosistem ini, peserta didik menjadi lebih aktif dalam pembelajaran dibandingkan dengan guru mata pelajaran karena adanya penugasan pada LKPD, serta dengan adanya LKPD ini membuat peserta didik lebih mengerti terhadap materi ekosistem karena penggunaan LKPD dilakukan di lingkungan sekolah untuk mengamati langsung keaadaan ekosistem di lingkungan sekolah tersebut, (2) Pada penelitian ini dihasilkan produk perangkat pembelajaran berupa Lembar Kerja Peserta Didik (LKPD) yang di dalamnya terdapat integrasi antara materi yang dipilih dalam penelitian yaitu materi ekosistem dengan Islam, sehingga dengan dilakukannya penelitian ini maka akan menambah pengetahuan peserta didik tentang pengintegrasian antara materi biologi khususnya materi ekosistem dalam Islam, (3) Produk Lembar Kerja Peserta Didik (LKPD) yang dihasilkan pada penelitian ini memeliki format penulisan yang sesuai dengan format yang dikemukakan oleh ahli, berbeda dengan Lembar Kerja Peserta Didik (LKPD) yang sebelumnya digunakan oleh guru di sekolah lokasi penelitian. 


\section{SIMPULAN}

Berdasarkan hasil penelitian dan pembahasan dari penelitian ini, maka dapat disimpulkan bahwa: (1) Pengembangan Lembar kerja peserta didik (LKPD) ini dilakukan dengan menggunakan model 4D, dimana terdiri dari 4 tahapan yaitu define (pendefinisian), design (perancangan), develop (pengembangan), dan disseminate (penyebaran), (2) Lembar Kerja Peserta Didik (LKPD) setelah dibuat dan dikembangkan tergolong kedalam kategori sangat valid dengan rata-rata kevalidan yang diperoleh yaitu 3.72, (3) Lembar Kerja Peserta Didik (LKPD) pada materi ekosistem yang telah dibuat dan dikembangkan memperoleh respon yang positif dari peserta didik dengan rata-rata respon peserta didik yaitu 2.95, dan (4) Lembar Kerja Peserta didik (LKPD) pada materi ekosistem yang telah dibuat dan dikembangkan berada pada kategori sangat efektif dengan persentase ketuntasan belajar peserta didik sebesar $92 \%$.

\section{UCAPAN TERIMA KASIH}

Ucapan terima kasih kepada pihak sekolah MA Madani Alauddin Pao-Pao dan MA Ash-Shalihin yang telah memfasilitasi dan memberikan arahan dalam pelaksanaan penelitian ini.

\section{DAFTAR PUSTAKA}

Desmiwati, R.R. \& Yulkifli. (2017). Validitas LKPD Fisika SMA Menggunakan Model Problem Based Learning Berbasis Teknologi Digital. Retrieved from http://www.jurnalmahasiswa.unesa.ac.id/article26135464/364/article.pd

Hasbullah, (2009). Dasar-Dasar Ilmu Pendidikan. Jakarta: PT. Raja Grafindo Persada.

Juanda, A. (2015). Profesionalisme Mahasiswa Biologi Mengintegrasikan Pelajaran Biologi dengan Agama Islam, Retrieved from https://www.syekhnurjati.ac.id/jurnal/index.php/sceducatia/article/view/483

Merdekawati, S., \& Lestari, H. P. (2011). Developing Student Worksheet In English Based On Constructivism Using Problem Solving Approach For Mathematics Learning On The Topic Of Social Arithmetics. International Seminar and the Fourth National Conference on Mathematics Education 2011 Department of Mathematics Education, Yogyakarta State University, 978-979.

Nahdaturrugaisiyah. (2017). Pengembangan Media Pembelajaran Berbasis Flash Pada Pokok Bahasan Sistem Organisasi Kehidupan Siswa SMP Negeri 24 Makassar, (Skripsi tidak diterbitkan). Universitas Islam Negeri Alauddin Makassar, Makassar.

Nissa, L.H. \& Sukardiyono. (2017). Pengembangan LKPD Fisika Dengan Strategi Pembelajaran Induktif Untuk Mengukur Keterampilan Berfikir Kritis Siswa, Retrieved from http://www.jurnalmahasiswa.unesa.ac.id/article26135464/364/article.pd

Ridwan. (2003). Skala Pengukuran Variable-Variabel Penelitian Cet. Kedua. Bandung: Alfabeta.

Sari, A.P.P. \& Agil L. (2016). Pengembangan Lembar Kegiatan Peserta Didik (LKPD) Berbasis Scientific Approach Siswa Sma Kelas X Pada Materi Fungi, Retrieved from http://fkip.ummetro.ac.id/journal/index.php/biologi/article/view/489

Sugiyono, (2013). Metode Penelitian Pendidikan Pendekatan Kuantitatis, Kualitatif dan $R \& D$. Bandung: Alfabeta. 
Sumarmi, Wiwik S.U., I. Nyoman R., dan Sugeng U., (2016). The Effectiveness of Geography Student Worksheet to Develop Learning Experiences for High School Students, Retrieved from http://files.eric.ed.gov/fulltext/EJ1111407.pdf

Undang-Undang Republik Indonesia Nomor 20 Tahun 2003 Tentang Sistem Pendidikan Nasional.

Widyoko, S. Eko Putro. (2014). Evaluasi Program Pembelajaran Panduan Praktis Bagi Pendidik dan Calon Pendidik. Yogyakarta: Pustaka Pelajar.

Yusuf, N. (2010). Perspektif Islam tentang Pengintegrasian Ilmu Akhlak dalam Pembelajaran Ilmu Sains dan Penerapannya di Lembaga Pendidikan Islam, Retrieved

from https://www.ejournal.uinsuska.ac.id/indeks.php/Kutubkhanah/article/download 4404/386 